\title{
RABIES LABORATORY DIAGNOSIS: PECULIAR FEATURES OF SAMPLES FROM EQUINE ORIGIN
}

\author{
Zélia M.P. Peixoto ${ }^{1}$; Elenice M. Sequetin Cunha ${ }^{1 *}$; Débora R.V. Sacramento ${ }^{1}$; M. Conceição A.M. Souza ${ }^{2}$ Luzia H. \\ Queiroz da Silva ${ }^{3}$; Pedro Leal Germano ${ }^{4}$; Suzana S. Kroeff ${ }^{1}$; Ivanete Kotait ${ }^{1}$
}

${ }^{1}$ Instituto Biológico, Seção de Raiva e Encefalomielite, São Paulo, SP, Brasil. ${ }^{2}$ Laboratório Regional de Pindamonhangaba, Instituto Biológico, São Paulo, SP, Brasil. ${ }^{3}$ Departamento de Apoio, Produção e Saúde Animal, Curso de Medicina Veterinária, Universidade Estadual Paulista, Araçatuba, SP, Brasil. ${ }^{4}$ Faculdade de Saúde Pública, Universidade de São Paulo, SP, Brasil

Submitted: September 24, 1998; Returned to author for corrections: October 14, 1999; Approved: April 06, 2000

\begin{abstract}
Rabies laboratory diagnosis is performed by using microscopic examination for Negri bodies (MEN), fluorescent-antibody test (FAT) and mouse inoculation test (MIT). In the majority of cases, when specimens are properly collected and conserved and the laboratory worker has good experience, agreement among employed techniques is verified. Comparing the sensitivity of these three diagnosis techniques in 3,713 samples (hippocampus and brain stem) received during 1981-1994 period, being 3,010 from bovine (983 positives) and 703 from equine (111 positives) species, it was observed that in equine rabid samples, this agreement was not maintained. For the latter specie, only in few opportunities the Negri bodies could be observed. With respect to FAT, the test detected a lower porcentage of positive equine samples compared to bovine species. Statistical analysis demonstrated that the difference was significative. Mouse inoculation test proved to be more sensitive. However, a significant difference in mice incubation period was observed for samples from both species. The absence of inclusion bodies and the longer incubation period for equine samples suggest that rabies pathogenesis studies for equine species have to be intensified.
\end{abstract}

Key words: equine rabies, laboratory diagnosis

\section{INTRODUCTION}

Rabies in herbivores in Brazil is determined mostly by the presence of the vampire bat. Bovine and equine may be included among the animal species most affected by the vampires. The laboratory diagnosis has fundamental importance so that control measures can be taken, and human treatment decisions may be recommended. Therefore, a reliable diagnostic method must be applied, utilizing adequate and recommended techniques, taking into consideration the limitations and failures of each method. The microscopic examination for Negri bodies (MEN), fluorescent antibody test (FAT) and mouse inoculation test (MIT) can be named among the most usual recommended techniques for rabies diagnosis $(5 ; 11 ; 17)$. The MEN is a fast and economical procedure (1), and is recognized worldwide as specific for rabies, since the presence of these corpuscles always indicates infection (17). The FAT is the most sensitive method for the detection of the rabies antigen in fresh samples (12) but requires, however, well-equiped laboratories. The isolation of the rabies virus, through MIT, confirms the results obtained by other techniques, although its use is expensve and slow (3).

In the equine species, rabies is clinically indistinguishable from other encephalitides $(9 ; 10)$, such as equine encephalomyelitis, herpesvirus, toxoplasmosis, listeriosis, leukoencephalomalacia, among others. Thus, its confirmation in the laboratory is of extreme importance. Some authors relate that in Europe, United States and Canada, the incidence of equine rabies is lower when compared to that of other species $(6 ; 18)$. Other authors mention that Negri bodies are not formed in equine nervous tissue (14) and relate a period of incubation in laboratory

\footnotetext{
* Corresponding author. Mailing address: Instituto Biológico, Laboratório de Raiva e Encefalites Virais, Av. Conselheiro Rodrigues Alves, 1252. CEP 04014 001. São Paulo, SP, Brasil. Fax: (+5511) 570-0824. E-mail: cunha@biológico.br
} 
mice of around 11 days for samples from the equine species (2).

Experience in performing laboratory diagnosis of rabies has shown that samples from equines differ from observations on other species. Thus, the objective of the current work was to compare sensitivity and agreement among the three techniques usually used in Brazil for the diagnosis of rabies, in bovine and equine species, in the period $1981-1994$.

\section{MATERIALS AND METHODS}

\section{Samples}

Fragments of the central nervous system of 3,010 samples of the bovine species and 703 of the equine species, with clinical suspect of rabies, were analyzed.

\section{Microscopic examination for Negri bodies (MEN)}

The survey for Negri bodies was performed from impressions of the Ammon's horn or cerebellum, using Sellers' stain (two parts methylene blue to one part basic fuchsin and methyl alcohol). The slides were washed in running water, dried at room temperature and observed under a common optical microscope (17). The Negri bodies can be observed in the cytoplasm and dendrites of the neurons, presenting an acidophilic stain, with basophilic internal granulations.

\section{Fluorescent antibody test (FAT)}

Slides containing impression smear of the nervous system were fixed with acetone and stained in a humid chamber at $37^{\circ} \mathrm{C}$ for 30 minutes. The anti-rabies polyclonal conjugate - FITC (fluorescein isothiocyanate)-labeled purified $\mathrm{IgG}$ of equine origin - was diluted with $10 \%$ of the brain of normal laboratory mice. The slides were washed twice by immersion in phosphate-

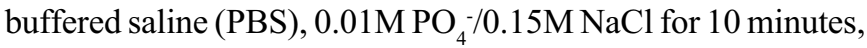
followed by washing in distilled water, and mounted with buffered glycerin.

\section{Mouse inoculation test (MIT)}

Eight 21-day-old albino Swiss laboratory mice, weighing $14 \mathrm{~g}$ average, were inoculated intracerabraly with $0.03 \mathrm{ml}$ of a suspension of each sample at $20 \%$ in a medium containing non vaccinated equine serum at $2 \%, 550 \mathrm{UI}$ penicillin $/ \mathrm{ml}$ and 1,560 UI streptomycin $/ \mathrm{ml}$. The animals were observed daily for a period of 30 days. The appearance of the symptoms (bristling of the fur, agitation, aerophobia, paralysis and death) was monitored. The incubation period of the sample was considered to be the first day of the appearance of the symptoms in one of the laboratory mice.

\section{Statistical Analysis}

For statistical analysis a sample was defined as positive when at least one of the three applied methods resulted positive.To compare the results of the percentage of sensitivity of each of the tests, and the percentage of agreement among tests, two by two, for samples of bovines and equines, the $\mathrm{Z}$ Test of two proportions was applied, with normal approximation. The level of significance of $\alpha=0.05$ and the cut-off point for $Z \alpha 5 \%=$ 1.96 were adopted.

To verify the possible difference between the average periods of incubation in laboratory mice, of samples of bovine and equine origin, the $\mathrm{Z}$ distribution with normal approximation was used. The level of significance of $\alpha=0.05$ and the cut-off point for $\mathrm{Z} \alpha 5 \%=1.96$ were used.

\section{RESULTS}

Table 1 shows the total of positive and negative samples analysed for rabies in the bovine and equine species and Table 2 presents the number of positive samples according to the each individual or associated methods. The sensitivities of the MEN and FAT methods for the samples of equine origin $(36.9 \%$ and $76.6 \%$, respectivelly) were lower than those observed for the samples of bovine origin ( $79.5 \%$ and $94.1 \%$, respectivelly). These differences were shown to be statistically significant, presenting $Z \alpha=6,355$ for MEN and $Z \alpha=5,908$ for FAT. What concerns MIT, comparing the samples of both species, the differences were not statistically significant, as can be observed in Table 3.

Table 1. Total of positive and negative rabies diagnosis from bovine and equine samples received during 1981-1994.

\begin{tabular}{|c|c|c|c|c|c|c|}
\hline \multirow{2}{*}{$\begin{array}{l}\text { Results } \\
\text { Species }\end{array}$} & \multicolumn{2}{|c|}{ Positive } & \multicolumn{2}{|c|}{ Negative } & \multicolumn{2}{|c|}{ Total } \\
\hline & $\mathrm{N}$ & $\%$ & $\mathrm{~N}$ & $\%$ & $\mathrm{~N}$ & $\%$ \\
\hline & 983 & 89.9 & 2027 & 77.4 & 3010 & 81.1 \\
\hline Equine & 111 & 10.1 & 592 & 22.6 & 703 & 18.9 \\
\hline Total & 1094 & 100.0 & 2619 & 100.0 & 3713 & 100.0 \\
\hline
\end{tabular}

Table 2. Number of positive samples, by species and individual or associated rabies diagnosis methods.

\begin{tabular}{lcccccccc}
\hline \multirow{2}{*}{ Species } & \multicolumn{2}{c}{ Bovine } & & \multicolumn{2}{c}{ Equine } & & \multicolumn{2}{c}{ Total } \\
\cline { 2 - 3 } Methods & $\mathrm{N}$ & $\%$ & & $\mathrm{~N}$ & $\%$ & & $\mathrm{~N}$ & $\%$ \\
\hline MEN & 1 & 0.1 & & 0 & 0.0 & & 1 & 0.1 \\
FAT & 30 & 3.1 & & 5 & 4.5 & & 35 & 3.2 \\
MIT & 57 & 5.8 & & 26 & 23.4 & 83 & 7.6 \\
MEN/FAT & 17 & 1.7 & & 2 & 1.8 & & 19 & 1.7 \\
MEN/MIT & 0 & 0.0 & & 0 & 0.0 & 0 & 0.0 \\
FAT/MIT & 115 & 11.7 & & 39 & 35.1 & & 154 & 14.1 \\
MEN/FAT/MIT & 763 & 77.6 & & 39 & 35.1 & & 802 & 73.3 \\
\hline TOTAL & 983 & 100.0 & 111 & 100.0 & 1094 & 100.0 \\
\hline
\end{tabular}

MEN - microscopic examination for Negri bodies

FAT - fluorescent antibody test

MIT- mouse inoculation test 
Table 3. Comparison between microscopic examination for Negri bodies (MEN), fluorescent antibody test (FAT) and mouse inoculation test (MIT) for the rabies diagnosis of positive samples from bovine and equine species.

\begin{tabular}{lccccccc}
\hline \multirow{2}{*}{ Species } & \multicolumn{2}{c}{ Bovine } & & \multicolumn{2}{c}{ Equine } & \multirow{2}{*}{ Z $\alpha$} \\
\cline { 2 - 3 } Thechnics & $\mathrm{N}$ & $\%$ & & $\mathrm{~N}$ & $\%$ & \\
\hline MEN & 781 & 79.5 & & 41 & 36.9 & $6.355^{*}$ \\
FAT & 925 & 94.1 & & 85 & 76.6 & $5.908^{*}$ \\
MIT & 935 & 95.1 & & 104 & 93.7 & 0.619 n.s. \\
\hline
\end{tabular}

* - significant

n.s. - not significant

Table 4. Agreement among the techniques for diagnosis of rabies, two by two, for the positive samples of bovine and equine origin.

\begin{tabular}{lccc}
\hline Concordance & $\begin{array}{c}\text { Bovine } \\
(\%)\end{array}$ & $\begin{array}{c}\text { Equine } \\
(\%)\end{array}$ & Z $\alpha$ \\
\hline MEN x FAT & 85.1 & 60.4 & $6.506^{*}$ \\
MEN x MIT & 80.7 & 40.0 & $9.596^{*}$ \\
FAT x MIT & 889.4 & 70.2 & $5.788^{*}$ \\
\hline
\end{tabular}

MEN - microscopic examination for Negri bodies

FAT - fluorescent antibody test

MIT- mouse inoculation test

* - significant

Considering the results obtained for the bovine and equine species, upon studying the percentage of agreement among the tests, two by two, statistically significant differences were noticed for MEN and FAT $(Z \alpha=6,506), \mathrm{MEN}$ and the MIT $(Z \alpha=9,596)$, as well as FAT and the MIT $(\mathrm{Z} \alpha=5,788)$ (Table 4).

In the MIT, the incubation period for the equine species (10.1 $+/-3.0$ days) was greater than for the bovine $(8.9+/-2.4$ days $)$. This difference was statistically significant $(\mathrm{Z} \alpha=3,695)$.

\section{DISCUSSION}

Laboratory confirmation of the clinical suspicion of rabies is essential for epidemiologist as well as for the veterinarian and the physician responsible for prescribing anti-rabies treatment for the exposed persons. On the other hand in the cases lacking laboratory confirmation, the prescribed treatment is generally interrupted. Therefore this laboratory diagnosis must, be trustworthy in terms of sensitivity and specificity, and also be quickly obtainable.

The results obtained in the present study show that the sensitivity of MEN method for the bovine species is within the expected parameters (79.5\%), which, according to the literature, presents from 80 to $90 \%$ correlation in suspected cases of rabies (1). Going against these data, the MEN did not prove to be adequate for the diagnosis of equine rabies, since its sensitivity was very low (36.9\%), compared to the data obtained from the samples of bovine origin. The results, however, are in agreement with those obtained by various authors who also concluded that in the equine species the visualization of the Negri bodies is inaccurate $(6 ; 7 ; 15)$.

The analysis of the results presented with the utilization of the FAT shows that, similar to what occurs with the MEN, the sensitivity was also less for the diagnosis of equine rabies (76.6\%) when compared to that of bovine rabies (94.1\%). This finding does not agree with the literature, which considers the detection of the rabies virus by this technique precise enough, that is, highly sensitive $(3 ; 12)$. The cerebral tissue is rarely negative for the detection of the rabies virus in the FAT. Nevertheless, studies show that this phenomenon may be due to a high level of antibodies in the brain, which could cover the viral antigen, or even due to replication of the virus in the lumbar region, resulting in sufficient neurological damage to the animal before reaching the brain $(13 ; 16)$. According to Green et al. (8), the Negri bodies are absent in $53 \%$ of the cases of equine rabies, and are more frequent when these animals survive 4 days or more.

The sensitivity of MIT was practically the same for the samples of equine and bovine origin. However, it must be emphasized that the incubation period observed for the equine samples was longer than for those of bovine origin. Studies conducted by Badiali et al. (2) demonstrated that the incubation period in laboratory mice inoculated with samples coming from the equines varied from 8 to 23 days, while the isolation of the virus from a donkey sample reached 24 days.

Despite the great sensitivity of immunofluorescence and its recommendation by World Health Organization (WHO) since the 1970's as a reference technique for the diagnosis of rabies (4), it is clear, from the results obtained, that, for the equine species, the diagnosis must always be confirmed by the isolation of the virus through the mouse intracerebral inoculation test.

According to Silva et al. (14), the detection of the rabies virus in equines, may be fruitless when the agent is surveyed in the brain and cerebellum. These authors mentioned two cases in which the virus was only diagnosed in the medulla and in the medulla oblongata. In this way, one more point of narrowing in the diagnosis of rabies in this species is ascertained.

These results may serve as a guide both for the procedures that will be adopted and for better interpretation of the obtained results. Still, the data presented in this study suggest that the norms for human treatment should be carefully reexamined when there is involvement of the equine species.

Keeping in mind the reduced number of publications about this subject, it is also suggested that further studies be conducted to elucidate the pathology and pathogenesis of the rabies virus in the equine species or, at least, to verify the portion of the nervous system most suitable for diagnosis. 


\section{RESUMO}

\section{Diagnóstico laboratorial da raiva: aspectos peculiares de amostras provenientes de equinos}

O diagnóstico laboratorial da raiva é realizado através de métodos de pesquisa do corpúsculo de Negri, imunofluorescência direta e inoculação em camundongos. $\mathrm{Na}$ maioria dos casos, quando a amostra é bem coletada, bem conservada e o profissional responsável possui experiência, verifica-se concordância entre as técnicas utilizadas. A Seção de Raiva e Encefalomielite do Instituto Biológico ao comparar a sensibilidade das três técnicas diagnósticas, em 3713 amostras (córtex cerebral, cerebelo e hipocampo) recebidas no período de 1980-1994, sendo 3010 da espécie bovina ( 983 positivas) e 703 da espécie eqüina (111 positivas), observou que, no caso da raiva eqüina, esta concordância não é mantida. Verificou-se, nesta espécie, que somente em algumas oportunidades foi possível identificar, pelo método histopatológico, o corpúsculo de Negri. Em relação à prova de imunofluorescência pode-se afirmar que a mesma detectou uma porcentagem menor de amostras positivas, provenientes da espécie equina, em compração com as da espécie bovina, sendo esta diferença estatisticamente significativa. A prova biológica foi a mais sensível, porém houve uma diferença, também significativa, entre o período de incubação em camundongos das amostras de origem bovina e das de origem eqüina. A presença pouco frequente de corpúsculos de Negri e o período de incubação em camundongos mais prolongado, das amostras de origem eqüina, sugerem que devem ser intensificados os estudos da patogenia da raiva nesta espécie.

Palavras-chave: raiva eqüina, diagnóstico laboratorial

\section{REFERENCES}

1. Acha, P.N.; Szyfres, B. Rabia. In: Zoonosis e enfermedades transmisibles comunes al hombre y a los animales. 2. ed. Washington, 1989, p.502526.

2. Badiali, L.; Ferris, D.H.; Abou-Youssef, M.; Radwan, A.; Handy, F. Stato attuale delle ricerche sulla encefalomielite equina in Egitto con particolare riferimento alla rabbiaVet. Ital., 18: 151-165, 1967.

3. Bourhy, H.; Sureau, P. Comparison des techniques de detection et d'isolement. In: Methodes de laboratoire pour le diagnostic de la rage. Institut Pasteur, Paris, 1990, p. 78-8.

4. Dean, D.J. Epreuve des anticorps fluorescents. In: Kaplan, M.M.; Koprovski, H. La rage. Techniques de laboratoire. 2è ed. Organization Mondiale de la Santé, 1967, p. 61-71.

5. Dean, D.J.; Abelseth, M.K.; Atanasiu, P. Routine laboratory procedures: The fluorescent antibody test. In: Meslin, F.X.; Kaplan, M.M.; Koprowski. Laboratory techniques in rabies. 4. ed. Genebra, World Health rganization, 1996, p. 88-95.

6. Dreesen, D.W. Equine rabies. Veterinary Reports, 1990, p. 1-5.

7. Ferris, D.H.; Badiali, L.; Abou-Youssef, M.; Beamer, P.D. A note on experimental rabies in the donkey. Cornell Vet., 58: 270-277, 1968.

8. 8.Green, S.L.; Smith, L.L.; Vernau, W.; Beacock, S. M. Rabies in horses: 21 cases (1970-1990). JAVMA, 200(8): 1133-1137, 1992.

9. Innes, J.P.M.; Sauders, L.Z. Comparative neuropathology. New York, Academic Press, 1962

10. Keane, D.P.; Little, B.L. Equine viral Encephalomielitis in Canada: A review of known and potencial causes. Can.Vet. J., 28: 497-504, 1987.

11. Koprowsky, H. Routine laboratory procedures: The mouse inoculation test In: Meslin, F.X.; Kaplan, M.M.; Koprowski. Laboratory techniques in rabies. 4. ed. Genebra, World Health Organization, 1996, p. 80-87.

12. Meslin, F.X.; Kaplan, M.M. An overview of laboratory techniques in the diagnosis and prevention of rabies and in rabies research. In: Meslin, F.X.; Kaplan, M.M.; Koprowski. Laboratory techniques in rabies. 4. ed. Genebra, World Health Organization, 1996, p. 9-16.

13. Meyer, E.E.; Morris, P.G.; Elcock, L.H.; Weil, J. Hindlimb hyperesthesia associated with rabies in two horses. JAVMA., 188(6): 629-632, 1986.

14. Silva, R.A.; Silva, N.M.; Menezes, P.R.V. Ocorrência do vírus da raiva na medula e no bulbo de eqüinos na doença natural e sua ausência nas diferentes regiões do sistema nervoso central e outro tecidos. Pesq. Agrop. Bras., Sér. Vet., 9: 29-31, 1974.

15. Smit, J.D. The diagnosis of rabies in the Republic of South Africa with a critical analysis of the histological findings. Bull. Off. int. Épiz., 60:163181. XXXI ${ }^{\mathrm{e}}$ Session Génerale, rapport $\mathrm{n}^{\mathrm{o}} 703,1963$.

16. Tabel, H.; Charlton, K.M. The diagnosis of rabies in a horse by brain neutralization test. Can. J. comp. Med., 38:344-346, 1974.

17. Tierkel, E.S.; Atanasiu, P. Routine laboratory procedures: Rapid microscopic examination for Negri bodies and preparation of specimens for biological tests. In: Meslin, F.X.; Kaplan, M.M.; Koprowski. Laboratory techniques in rabies. 4. ed. Genebra, World Health Organization, 1996, p.55-65.

18. West, G.P. Equine rabies. Equine Vet. J., 17(4): 280-282, 1985. 